\title{
Social Development of Iraqi Governorates in Comparison
}

\author{
Iftikhar I. M. Naqash \\ University of Mustansiriya, Iraq
}

Copyright $\bigcirc 2017$ by authors, all rights reserved. Authors agree that this article remains permanently open access under the terms of the Creative Commons Attribution License 4.0 International License

\begin{abstract}
Inequitable distribution of investment funds on governorates and the autonomy of the Kurdistan Region with own investment policy are often mentioned as the main causes of the huge regional differences in social development in Iraq. In this paper, the differences in social development among 18 Iraqi governorates will be analyzed by using two different methods: first, 12 indicators of education, health and economic level are given equal weights and the length of the distance between every governorate and the governorate with the maximum standardized score for each individual indicator is combined into a Composite Regional Social Development Index $\left(\mathrm{CRSDI}_{\text {equal }}\right)$; second, unequal weights are given for each indicator depending on the indicator's loading in the first principal component to identify the weight of that indicator in a Composite Regional Social Development Index (CRSDI unequal). Both methods will result in the same ranking of the 18 governorates with respect to their social development level.
\end{abstract}

Keywords Social Development, Social Index, Composite Regional Social Development Index, Principal Component, Human Development Index, Physical quality of Life Index

\section{Introduction}

Development is a process of social change, not merely a set of policies and programs instituted for some specific results. Social Development refers to qualitative changes in the structure and functioning of the society that help the society to better realize its aims and objectives. Measuring Social Development is difficult because it requires the combined interpretation of many possible indicators. The objective established by the Organization for Economic Co-operation and Development (OECD, 1973: page 7) [14], council was to" undertake a concerted effort to achieve standardized definitions of the social goal areas for which systematic indicators and assessments are most needed, and to develop the central concepts and principles which could guide the organization and member governments in the preparation of such indicators". Atkinson et al. (2002: page
2) [2] saw social index (SI) as "a parsimonious set of specific indices covering a broad range of social concerns." This set includes statistics similar to economic statistics of the national accounts which are intended to provide a basis for making concise, comprehensive and balanced judgments about the conditions of major aspects of society as accurate measures of a good society. The concept covers interpretation of cultural signs, simple statistical measures, and complex statistical indexes related to sets of domains. These are used to assess the effectiveness of policy in addressing important social issues.

In this context it is important to note that Morris (1979) combined three indicators (life expectancy at birth, infant mortality and adult literacy) to construct the physical quality of life index (PQLI) and used it for a cross-country comparison. This was a pioneering attempt in constructing a composite index of development. Ray (1989) [16] used as many as 13 physical indicators in the construction of a composite index (SDI) for measuring social development across 40 countries. UNDP has introduced human development index (HDI) for a large number of countries in 1990 and has been bringing out HDI every year since then. HDI is based on three indicators, namely, life expectancy at birth; educational attainment as measured by a combination of adult literacy and the combined first-, second- and third-level gross enrolment ratio; and standard of living measured by real GDP per capita (PPP\$). While both PQLI and HDI similarly consider only three indicators, the main difference between the two is the inclusion of income in HDI and the exclusion of the same from PQLI. Thus, the HDI represents both physical and financial attributes of development whereas the PQLI only the physical aspects of life. In contrast, the SDI captures 13 physical social indicators to represent more areas of social concern. Further, PQLI and HDI are weighted sums of indicators having equal weights. SDI, on the other hand, is associated with an objective method of deriving weights for combining multiple physical indicators.

In this paper argues the regional disparities of Social Development level in the Iraqi governorates, a number of indicators (12) socio-economic indicator of Education, Health and Economic are employed to compare (18) governorate of Iraq. Applied two different methods to 
compute the Social Development Index, the first consider the length of the distance vector between every governorate and the governorate with the maximum standardized score for individual indicator (the governorate with ideal score), combining them into a Composite Regional Index (equal weights)and there by ranking governorates with respect to their Social Development level $\left(\mathrm{CRSDI}_{\text {equal }}\right)$, the second method dependent essentially on the Principal Component techniques consider the variables loading in the first Principal Component to identified the weights indicators (unequal weights) in this Social Development Index

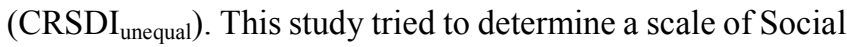
Development priorities for the Iraqi governorates in the.

This study is divided in four sections. Section 1 deals with methodological issues of using social indicators having equal weights and those of assigning weights to the indicators for obtaining a composite regional social development index (CRSDI). In section 2, the data set of the analysis will be presented and discussed. Then, section 3 displays the empirical results across Iraqi governorates. This section consists of two subsections: one deals with the composite development index having equal weights, and the other with the unequal weights approaches that we use. Finally, section 4 sets out some conclusion. The appendix contains empirical results.

\section{Methodological Issues}

There had been some attempts in the past for construction of a composite index of development by combining indicators, but such efforts have been gaining acceptance after the introduction of PQLI. United Nations Research Institute for Social Development (UNRISD) laid emphasis in improving development statistics since the early 1960s. The living indexes of Drewnowski and Scott (1966) and McGranahan et al. (1972) [9] are examples of the early attempts in measuring the level of living and the basic needs.

There are various methods of combining different indicators into a composite index which can be classified in two broad categories: First, intuitive methods which consider the indicators as equally important (equal weights), and second, objective methods which consider some indicators as more important than others assigning them different weights. One method from each category will be displayed below.

\subsection{Distance Matrix}

We start with the matrix of data, X, containing data on (m) social indicators for (n) governorates. To remove the scale effect and to have the indicators spread around the same mean with the same variance, we first standardize the data. Conceptually social development should be defined within the context of all governorates as the length of standardized indicator equal to the square root of the number of governorates, the length of the standardized indicator vectors being equal. With this property, these vectors can constitute the axes of a space which each governorate being presented by a vector. In the standardized data matrix each governorate can be mapped as an $\mathrm{m}$ - dimensional vector in the space of the selected indicators. The distance between any two such vectors may then be measured by the length of the so-called distance vector.

We can be concerned with the distance vector between governorate (i) and the governorate with the maximum standardized score (ideal score) for an individual governorate. The length of the distance vector $\left(d_{i}\right)$ from the ideal governorates for governorate (i) containing (m) components is then measured by

$$
d_{i}=\sqrt{\sum_{j=1}^{m}\left(z_{i j}-z_{0 j}\right)^{2}} \mathrm{i}=1,2,3, \ldots \mathrm{n}
$$

where $\left(z_{0 j}\right)$ is the highest standardized score for indicator ( j ). The lower the $\left(d_{i}\right)$ the better the position of governorate (i) relative to the ideal governorate. We can rank different governorates according to the value of $\left(d_{i}\right)$.

We may wish to express these measures in the form of an index whose values are between 1 and 0 . In fact we have a number of options. We may follow the approach suggested by Noorbakhsh (1998)[12] and define the Composite Social Development Index (CRSDI) as follows:

$$
S D I_{i}=1-\frac{d_{i}}{\bar{d}+k S_{d}} \mathrm{i}=1,2,3, \ldots \mathrm{n}
$$

where $\bar{d}$ and $S_{d}$ are the mean and standard deviation of $d_{i}, \mathrm{k}$ is the normal deviate corresponding to the confidence probability. So, $\mathrm{k}=2.57$ present table value on a $\mathrm{t}$ distribution with significance level (0.99). In practice, for approximation value $\mathrm{k}=2.6$ all governorate fell within the required range.

\subsection{Principal Component Analysis}

Principal Component Analysis is a standard statistical tool, (Biswas and Caliendo, 2001-2002)[3] have used the first principal component of the variance covariance matrix of the HDI indicators (life expectancy, education and GDP) as an alternative to HDI, they observed that the HDI 2001 rankings of 162 countries are largely consistent with the first principal component.

Principal Components are linear combinations of random variables which have special properties in terms of variances; the principal components turn out to be the characteristic vectors of the covariance matrix. In effect transforming the original vector variable to the vector of principal components amounts to a rotation of coordinate axes to a new coordinate system that has inherent statistical properties.

Suppose the random vector $\mathrm{X}$ of $(\mathrm{m})$ components has the covariance matrix $\sum$, we shall assume that the mean vector is zero. 
Let $\mathrm{B}$ be m-component column vector such that $\mathrm{B}^{\prime} \mathrm{B}=1$ the variance of $\mathrm{B}^{\prime} \mathrm{X}$ is $\mathrm{B}^{\prime} \sum \mathrm{B}$.

To determine the normalized linear vector $\mathrm{B}$ satisfying $\mathrm{B}^{\prime} \mathrm{B}=1$ which maximizes $\mathrm{B}^{\prime} \sum \mathrm{B}$

Let

$$
\varnothing=\mathrm{B}^{\prime} \sum \mathrm{B}-\lambda\left(\mathrm{B}^{\prime} \mathrm{B}-1\right)
$$

where, $\lambda$ is a La-Grange multiplier.

Set the partial derivatives of the above equation to zero in other words $\lambda$ must satisfy.

$$
\left|\sum-\lambda \mathrm{I}\right|=\mathrm{O}
$$

The function $\left|\sum-\lambda \mathrm{I}\right|$ is a polynomial in $\lambda$ of degree $\mathrm{m}$ (has $\mathrm{m}$ roots), let these be

$$
\lambda_{1} \geq \lambda_{2} \geq \lambda_{3} \geq \ldots \ldots \geq \lambda
$$

Thus for the maximum variance we should use the largest root $\lambda_{1}$, the first principal components is the normalized linear combination with maximum variance.

Now, we able to calculate index number measures the level of the social development for every governorate, by using the loading of variables in the first principal component as explain below

$$
\begin{gathered}
S D I_{i}=\sum_{j=1}^{m} W_{J} X_{J} \mathrm{i}=1,2,3, \ldots 18 \\
W_{J}=d * \frac{a_{j}}{S_{J}} 1.6 \\
d=\frac{100}{\sum_{j=1}^{m} \frac{a_{j}}{S_{J}}} \bar{x}
\end{gathered}
$$

\section{Data Set}

Up to 2003, data shortages prevented a comprehensive assessment of the country human development situation, making it impossible to calculate indices comparable to those used in the global and Arab human development reports.

Since 2004, New surveys conducted by the Central Organization for Statistics and Information's Technology (COSIT), Including

1) Iraqi Living Conditions Survey (ILCS, 2004).

2) The Multiple Indicator Cluster Survey (MICS, 2006, 2011).

3) Iraq Household Social and Economic Survey (IHSES, 2008).

4) Iraq National Report on the status of Human Development (INRHD, 2008).

5) Iraq Knowledge Network Survey (IKNS, 2011).

Have permitted the better measurement of national (HD) indicators, surveys was designed to visit 18,144 households - 324 households in each of 56 strata, defined as the rural, urban, and metropolitan portions of each of Iraq's 18 governorates. Baghdad, with five strata, was the exception. In all, 972 households were selected in each governorate, except Baghdad where the sample size was 1,620 households, including Kurdistan region. Even a statistical view may be taken that in a setup of a too few indicators, any one indicator containing error or large variation would affect the index unduly could exclusion it. Also in the development process, like the positive aspects, the negative aspects also need to be recognized. Such indicators, which are considered negative to the development, may be systematically replaced by some equivalent inverse functions. A number of concern areas and indicators representing the areas need to be suitably selected for analysis of various aspects of development, unless the purpose of the study is very restrictive. These initiatives will allow to making comparison across governorates, from this it was clarify that the eighteen governorates of the country have witnessed disparity in the social development levels. This disparity reflects a phase of education, health and economics for the human being luxury. Therefore, The data cover twelve social indicators, these indicators represent a subset of the social indicators set identified by the basic list of Sustainable Development Committee (2000). While indicators provide partial measures of development in respect of concern areas a composite index of development based on the selected indicators is considered reflecting the overall development. It is not, however, possible to include all the aspects of development in a composite index and the selected indicators should have the property of beings operational. The present study has 12 social indicators representing various areas of social concern across eighteen governorates of Iraq, The number of indicators selected for the study may be considered as large. However, in the construction of SDI the choice of multi-dimensional indicators is treated as flexible. The indicators selected for the study are

1) Gender proportion of primary school enrolment.

2) Gender proportion secondary school enrolment.

The rate of girls to boys attending primary and secondary education, these rates are better known as the gender parity index(GPI), represent (Number of children of primary school age currently attending primary or secondary school /Total number of children of primary school age or secondary school age).

3) Female adult literacy rate as a percentage of population aged 15 years and older, known as Literacy rate among young women, represent (Number of women age 15-24 years who are able to read a short simple statement about everyday life or who attended secondary or higher education / Total number of women age 15-24 years).

4) Percentage of population with chronic disease conditions, represent (Number of household members with chronic disease / Total number of household members).

5) Percentage of population having safe drinking water, 
represent (Number of household members using improved sources of drinking water / Total number of household members).

6) Percentage of population having sanitation facilities, represent (Number of household members using improved sanitation facilities / Total number of household members).

7) Percentage of population whose garbage disposal is collected by municipality, represent (Number of household members whose garbage disposal is collected by municipality / Total number of household members).

8) Proportion of urban population, COSIT; Estimates of the population in Iraq (Number of members in urban regions / total number of members (population).

9) Per capita GDP by current prices, COSIT; Adjusted the per capita GDP on the level of Iraq; by weighted it's in the per capita expenditure level in each governorate to get to the Per capita GDP for that Governorate.

10) Per capita nominal expenditure on main groups at market prices, represent the total of average per capita nominal expenditure on main groups(Food-stuffs and non-alcoholic beverages, Alcoholic beverages; Tobacco and Narcotics, Clothing and Foot wear, Dwellings; Water; Gas; Electricity and Fuel, Houehold Furnishings; Equipment and Supplies, Health, Transport, Communication, Recreation and Culture, Education, Restaurants and Hotels, Miscellaneous Commodities and Services) at market prices (ID000/month).

11) Gender unemployment rate, represent (unemployment rate for women $\%$ / unemployment rate for men $\%$ ).

12) Percentage of population having computer, represent (Number of household members having computer / Total number of household members).

\section{Empirical Results}

The values for above indicators are presented in Table 1.

\subsection{Equal Weighted Method (CRSDI equal $)$}

Consider now the formulation 1.1 to measures the CRSDI $_{\text {equal }}$. Ranks of 18 governorates in the social development index are presented in Table 1 . For this, the values of distance have been formed as an index with values between 1 and 0 according to the above formula 1.2. The values of CRSDI closer to 1 mean that the corresponding governorate is more developed in terms of the selected indicators, and vice versa. The fourth column of Table 1 shows the difference in the value of $\mathrm{CRSDI}_{\text {equal }}$ between governorates from governorate with the highest CRSDI in the table.

The value for the distance between the top governorate Sulaimaniya and all the other governorates except Erbil, Duhouk, Baghdad and Najaf is strikingly, indicating that governorate Sulaimaniya is by far the most advanced in the field of social development, also the social development index for governorates of Arbil and Dohuk closest to Sulaimaniya in social development index, the distance between each of them and the governorate of Sulaymaniyah does not exceed 0.1 , that is mean, Kurdistan region are generally ranked first in the field of social development because of security stability in kurdistain region comes in second place the capital Baghdad due to focus social and economic activities in it. while Najaf governorate came in third place because of sanctity and status of this governorate in the world Islamic, which led to the stability and activity of religious tourism and high traffic social development for this governorate compared to the rest governorates of Iraq, in other words Najaf governorate ranked first in social development among governorates of Iraq except Kurdistan region and Baghdad. 
Table 1. Values of the data set used in the analysis

\begin{tabular}{|c|c|c|c|c|c|c|c|c|c|c|c|c|}
\hline \multirow[b]{2}{*}{ Governorates } & \multicolumn{2}{|c|}{ Gender proportion of } & \multirow{2}{*}{$\begin{array}{l}\text { Female dult } \\
\text { Literacy Rate } \\
\text { Percentage of } \\
\text { Population } \\
\text { aged } 15 \text { years } \\
\& \text { older } \\
\end{array}$} & \multicolumn{4}{|c|}{ Percentage of population } & \multirow[b]{2}{*}{$\begin{array}{l}\text { Proportion of } \\
\text { Urban } \\
\text { Population }\end{array}$} & \multirow[b]{2}{*}{$\begin{array}{c}\text { Per capita } \\
\text { GDP by } \\
\text { Current } \\
\text { Prices }\end{array}$} & \multirow{2}{*}{$\begin{array}{l}\text { Per Capita } \\
\text { Nominal } \\
\text { Expenditure } \\
\text { on main } \\
\text { groups at } \\
\text { market prices } \\
\end{array}$} & \multirow[b]{2}{*}{$\begin{array}{c}\text { Gender Un } \\
\text { employment } \\
\text { Rate }\end{array}$} & \multirow{2}{*}{$\begin{array}{c}\text { Percentage } \\
\text { of } \\
\text { Population } \\
\text { having } \\
\text { Computer }\end{array}$} \\
\hline & $\begin{array}{c}\text { Primary } \\
\text { School } \\
\text { Enrolment }\end{array}$ & $\begin{array}{l}\text { Secondary } \\
\text { School } \\
\text { Enrolment }\end{array}$ & & $\begin{array}{l}\text { With } \\
\text { Chronic } \\
\text { Disease }\end{array}$ & $\begin{array}{l}\text { Having } \\
\text { Safe } \\
\text { Drinking } \\
\text { Water }\end{array}$ & $\begin{array}{c}\text { Having } \\
\text { Sanitation } \\
\text { Facilities }\end{array}$ & $\begin{array}{c}\text { Garbage } \\
\text { Disposal by } \\
\text { Municipality }\end{array}$ & & & & & \\
\hline Nineveh & 0.84 & 0.44 & 45 & 9.2 & 83.7 & 93.3 & 14.4 & 60.7 & 3361 & 124 & 0.374194 & 5 \\
\hline Kirkuk & 0.85 & 0.59 & 50 & 9.6 & 97.7 & 93.6 & 19.6 & 69.1 & 3998 & 145 & 1.865672 & 3 \\
\hline Diala & 0.93 & 0.79 & 63 & 7.4 & 72.5 & 95.8 & 6.7 & 41.4 & 3007 & 113 & 1.162437 & 2 \\
\hline Al-Anbar & 0.9 & 0.63 & 62 & 6.5 & 94.2 & 99.4 & 18.6 & 51.7 & 3518 & 121 & 0.651163 & 5 \\
\hline Baghdad & 0.98 & 0.84 & 54 & 11.3 & 95.6 & 99.5 & 32.9 & 86.7 & 3936 & 149 & 1.304348 & 9 \\
\hline Babylon & 0.83 & 0.72 & 49 & 7.8 & 63.9 & 83.4 & 10.5 & 46.9 & 3066 & 112 & 0.925 & 2 \\
\hline Kerbela & 0.92 & 0.84 & 55 & 7.6 & 90.3 & 91.8 & 44.4 & 64.8 & 3104 & 110 & 1.448276 & 3 \\
\hline Wasit & 0.84 & 0.7 & 46 & 8 & 71 & 94.1 & 23.2 & 52.1 & 3165 & 117 & 1.088235 & 3 \\
\hline Salahuddin & 0.81 & 0.46 & 41 & 6.7 & 72.5 & 92.8 & 11.1 & 45.9 & 2985 & 104 & 0.227273 & 2 \\
\hline Al-Naiaf & 0.89 & 0.87 & 53 & 12.7 & 88.1 & 93.2 & 43.1 & 68.6 & 3548 & 136 & 2.133333 & 3 \\
\hline Al-Qadisiya & 0.81 & 0.85 & 47 & 13.4 & 74.5 & 63.5 & 25 & 51.9 & 3132 & 116 & 0.792593 & 2 \\
\hline Al-Mathanna & 0.73 & 0.72 & 42 & 8.7 & 53.1 & 81 & 15.6 & 44 & 2728 & 99 & 0.176829 & 1 \\
\hline Thi-Qar & 0.84 & 0.74 & 44 & 7.2 & 69.9 & 80.8 & 12.2 & 58 & 3086 & 109 & 0.882629 & 1 \\
\hline Missan & 0.67 & 0.73 & 50 & 8.4 & 75.1 & 83.1 & 8.1 & 64.8 & 3214 & 114 & 0.349515 & 2 \\
\hline Basrah & 0.92 & 0.75 & 38 & 8.6 & 79.7 & 87.6 & 18.6 & 78.2 & 3155 & 120 & 1.260504 & 3 \\
\hline Duhuk & 0.97 & 0.92 & 68 & 15.6 & 98.6 & 98.1 & 74.8 & 73.2 & 4886 & 223 & 0.894118 & 5 \\
\hline Suleimaniya & 0.96 & 1.08 & 65 & 13.9 & 95.5 & 97.1 & 66.6 & 70.1 & 6637 & 297 & 1.4375 & 7 \\
\hline Erbil & 0.93 & 0.84 & 68 & 18.9 & 97.2 & 98.2 & 80.4 & 75.9 & 6042 & 293 & 1.315789 & 6 \\
\hline
\end{tabular}




\subsection{Unequal Weighted Method (CRSDI $\left.{ }_{\text {unequal }}\right)$}

Table 2. Ranking of the governorates by the value of $\mathrm{CRSDI}_{\text {equal }}$ Index

\begin{tabular}{|c|c|c|c|c|}
\hline Governorate & Distance & CRSDI & Difference & Rank \\
\hline Al-Muthanna & 10.69971 & 0.220822 & 0.589116 & 18 \\
\hline Salahuddin & 10.36377 & 0.245286 & 0.564652 & 17 \\
\hline Thi Qar & 9.299688 & 0.322775 & 0.487163 & 16 \\
\hline Babil & 9.28216 & 0.324051 & 0.485887 & 15 \\
\hline Al-Qadisiya & 8.994315 & 0.345013 & 0.464925 & 14 \\
\hline Ninevah & 8.834201 & 0.356673 & 0.453265 & 13 \\
\hline Missan & 8.751708 & 0.36268 & 0.447258 & 12 \\
\hline Diala & 8.649688 & 0.370109 & 0.439829 & 11 \\
\hline Wasit & 8.472408 & 0.383019 & 0.426919 & 10 \\
\hline Al-Anbar & 8.011092 & 0.416613 & 0.393325 & 9 \\
\hline Basrah & 7.991796 & 0.418019 & 0.391919 & 8 \\
\hline Kirkuk & 7.222112 & 0.474069 & 0.33869 & 7 \\
\hline Kerbela & 7.128064 & 0.480918 & 0.32902 & 6 \\
\hline Al-Najaf & 6.07861 & 0.557341 & 0.252597 & 5 \\
\hline Baghdad & 5.288242 & 0.614898 & 0.19504 & 4 \\
\hline Duhouk & 3.971247 & 0.710804 & 0.099134 & 3 \\
\hline Erbil & 2.818155 & 0.794775 & 0.015163 & 2 \\
\hline Sulaimaniya & 2.609943 & 0.809938 & & 1 \\
\hline
\end{tabular}

The unequal weights $(\mathrm{Wj})$ have been identified according to the method of principle component using the social sciences statistical package (SSPS). The results are presented in appendix tables B and C. According to the above formulas 1.6 and 1.7, the weights in the last column of Table 2 are calculated.

Consider now the above formula 1.5 to measures the CRSDI $_{\text {unequal. }}$ Ranks of the 18 governorates in the social development index are presented in Table 3. For this, the CRSD-Values have been formed as an index with values between 1 and 0 according to the above formula 1.2. The values of CRSDI closer to 0 mean that the corresponding governorate is more developed in terms of the selected indicators, and vice versa. The fourth column of table 3 shows the difference in the value of CRSDI between governorates from governorate with the highest CRSDI in the table.

Table 3. Calculation of the weights by using the first principal component

\begin{tabular}{|c|c|c|c|c|c|c|}
\hline $\begin{array}{c}\text { Indicator } \\
\text { (Variables) }\end{array}$ & $\begin{array}{c}\text { Loading Component } \\
\mathrm{a}_{\mathrm{j}}\end{array}$ & $\begin{array}{c}\text { Mean } \\
\bar{X}\end{array}$ & $\begin{array}{c}\text { Standard } \\
\text { Deviation } \\
\mathrm{S}_{\mathrm{j}}\end{array}$ & $\mathrm{aj} / \mathrm{sj}$ & (aj/sj)* & $\mathrm{W}$ \\
\hline $\mathrm{X}_{1}$ & 0.284 & .8678 & .08229 & 0.034513 & 2.994972 & 0.144427 \\
\hline $\mathrm{X}_{2}$ & 0.7 & .7506 & .15588 & 0.044905 & 3.370394 & 0.187915 \\
\hline $\mathrm{X}_{3}$ & 0.661 & 52.222 & 9.4654 & 0.069833 & 3.646795 & 0.29223 \\
\hline $\mathrm{X}_{4}$ & 0.889 & 10.083 & 3.4772 & 0.25394 & 2.560565 & 1.062665 \\
\hline $\mathrm{X}_{5}$ & 0.064 & 90.350 & 9.1398 & 0.007002 & 0.632662 & 0.029303 \\
\hline $\mathrm{X}_{6}$ & 0.37 & 81.839 & 13.4965 & 0.027411 & 2.243289 & 0.114705 \\
\hline $\mathrm{X}_{7}$ & 0.838 & 29.211 & 23.3008 & 0.035964 & 1.050557 & 0.1505 \\
\hline $\mathrm{X}_{8}$ & 0.329 & .61 .333 & 13.1010 & 0.025113 & 1.54023 & 0.105089 \\
\hline $\mathrm{X}_{9}$ & 0.837 & 3698.22 & 1085.889 & 0.000771 & 2.850577 & 0.003226 \\
\hline $\mathrm{X}_{10}$ & 0.881 & 144.48 & 61.327 & 0.014366 & 2.075524 & 0.060116 \\
\hline $\mathrm{X}_{11}$ & 0.134 & 1.016 & .5424 & 0.247066 & .251038 & 1.033898 \\
\hline $\mathrm{X}_{12}$ & 0.416 & 3.56 & 2.175 & 0.191236 & 0.67995 & 0.800266 \\
\hline
\end{tabular}

Table 4. Ranking of the governorates by the value of $\mathrm{CRSDI}_{\text {unequal }}$ Index

\begin{tabular}{|c|c|c|c|c|}
\hline Governorate & $\begin{array}{c}\text { CRSD- } \\
\text { Value }\end{array}$ & CRSDI & Difference & Rank \\
\hline Salahudin & 74.66065 & 0.525669 & 0.456721 & 18 \\
\hline Al-Muthanna & 76.7631 & 0.512311 & 0.443363 & 17 \\
\hline Thi qar & 83.09663 & 0.472074 & 0.403126 & 16 \\
\hline Babil & 83.57659 & 0.469024 & 0.400076 & 15 \\
\hline Missan & 85.19401 & 0.458749 & 0.389801 & 14 \\
\hline Ninevah & 86.89306 & 0.447954 & 0.379006 & 12 \\
\hline Wasit & 87.87983 & 0.441685 & 0.372737 & 11 \\
\hline Diala & 90.31161 & 0.426236 & 0.357288 & \\
\hline Basrah & 91.45275 & 0.418986 & 0.350038 & \\
\hline AL-qadisiya & 94.77206 & 0.397898 & 0.328950 & \\
\hline Al-anbar & 95.08060 & 0.395937 & 0.326989 & \\
\hline Kirkuk & 98.26330 & 0.375717 & 0.306769 & 7 \\
\hline Kerbela & 100.30940 & 0.362718 & 0.293770 & 6 \\
\hline Al-najaf & 108.93490 & 0.307919 & 0.238917 & 5 \\
\hline Baghdad & 115.84710 & 0.264004 & 0.195056 & \\
\hline Duhouk & 134.96310 & 0.142557 & 0.073609 & \\
\hline Sulaimaniya & 145.48100 & 0.075735 & 0.006787 & 3 \\
\hline Erbil & 146.54940 & 0.068948 & & 2 \\
\hline
\end{tabular}


Also Kurdistan region in the forefront governorates of Iraq in social development level, where Arbil governorate ranked first, followed by Sulaymaniyah and Dohuk governorates, While other governorates occupied ranks from fourth place to the Baghdad governorate's the capital of Iraq, it is considered the most developed (ranked first) with the exception of Kurdistan region, to the eighteenth place to the governorate Salah al-Din the governorate have lowest developed between all governorates of Iraq.

Unstable security in the Iraqi governorates except Kurdistan region, is clearly reflected on the level of development in general and on the level of social development (social development index) in particularly and The disparity in investment allocations for each governorate shares within the annual investment budget for Iraq with a focus on raising social development in the capital level (ranked first in the calculated social development methods in the governorates of Iraq, except governorates of Kurdistan region guide).

\section{Conclusions}

This study confirmed that the levels of Social Development in terms of education, health and economic activity in Iraqi governorates are strongly unequal. This divergence is the outcome of, first, the autonomy of the Kurdish governorates Dohuk, Erbil and Sulaimania with their own development planning and investment policy and, second, the disparity in allocation of investment funds to the other Iraqi governorates in the annual investment budget. Remarkable is the concentration of the investment in the capital Bagdad which ranked first in the CRSDI in both methods, except governorates of Kurdistan region.

The two methods used to calculate CRSDI displayed that the highest level of social development is realized in the three governorates of Kurdistan Region. Medium level of social development was realized in the capital Baghdad, in the northern and most of the central governorates (Nienvah, Kirkuk, Diala, Babil, Alnajaf, and Kerbela). The lowest level of social development was found in the central governorates Salahulddin, Al-anbar and in all the southern governorates (Al Muthanna, Thi qar, Al Qadisiya, Wasit, Missan, Basrah). Both methods of calculation resulted in similar rankings for $50 \%$ of the governorates (Duhok, Bagdad, Alnajaf, Kerbela, Kirkuk, Diala, Nienvah, Babil, Thi qar) and in simple changes of 1, 2 degree in rankings of the other governorates, except for Al Qadisiya governorate which changed by 5 degrees in ranked in the two methods, The value of the distance between the Social Development Index $\left(\mathrm{CRSDI}_{\text {unequal }}\right)$ of the governorate Erbil to each other governorates of Iraq is less than the value of the distance between the Social Development Index method (CRSDI $\left.{ }_{\text {equal }}\right)$ of the governorate Sulaimaniya to each other governorates emphasizes the need to take the relative importance of each indicator into account when calculating social development index.
The most important variables in ranking the governorates in the second method are gender unemployment rate, and percentage of population with chronic disease conditions and having computer.

Finally, the results tried to determine scale priorities for the social development in Iraqi governorates that may be of benefit in achieving a balanced social development process in all governorates.

\section{Appendix}

Appendix A. Eigen Value, Proportion Factor Variance from Total Varianceand Cumulative Factor Variance

\begin{tabular}{|c|c|c|c|}
\hline Factor & $\begin{array}{c}\text { Eigen value } \\
(\lambda \mathrm{i})\end{array}$ & $\%$ of Variance & Cumulative $\%$ \\
\hline 1 & 7.227 & 60.221 & 60.221 \\
\hline 2 & 1.487 & 12.389 & 72.610 \\
\hline 3 & 1.047 & 8.721 & 81.333 \\
\hline 4 & .831 & 6.923 & 88.256 \\
\hline 5 & .427 & 3.561 & 91.817 \\
\hline 6 & .294 & 2.447 & 94.264 \\
\hline 7 & .260 & 2.166 & 96.430 \\
\hline 8 & .196 & 1.633 & 98.063 \\
\hline 9 & .139 & 1.160 & 99.223 \\
\hline 10 & .077 & .638 & 99.861 \\
\hline 11 & .016 & .133 & 100.000 \\
\hline 12 & .001 & .005 & \\
\hline
\end{tabular}

Appendix B. Rotated Component Matrix, Communality Variance and Specific Variance

\begin{tabular}{|c|c|c|c|c|c|}
\hline \multirow{2}{*}{$\begin{array}{l}\text { Variables } \\
\text { (Indicator) }\end{array}$} & \multicolumn{3}{|c|}{$\begin{array}{l}\text { Principal component } \\
\text { (Loading Factor) }\end{array}$} & \multirow{2}{*}{$\begin{array}{l}\text { Communality } \\
\text { Variance }\end{array}$} & \multirow{2}{*}{$\begin{array}{l}\text { Specific } \\
\text { Variance }\end{array}$} \\
\hline & I & II & III & & \\
\hline $\mathrm{X}_{1}$ & .284 & .615 & .534 & .7440 & .2560 \\
\hline $\mathrm{X}_{2}$ & .700 & -.141 & .519 & .7792 & .2208 \\
\hline $\mathrm{X}_{3}$ & .661 & .493 & .093 & .6886 & .3114 \\
\hline $\mathrm{X}_{4}$ & .889 & .095 & .241 & .8574 & .1426 \\
\hline $\mathrm{X}_{5}$ & .064 & .921 & .086 & .8597 & .1403 \\
\hline $\mathrm{X}_{6}$ & .370 & .713 & .434 & .8336 & .1664 \\
\hline $\mathrm{X}_{7}$ & .838 & .315 & .302 & .8927 & .1073 \\
\hline $\mathrm{X}_{8}$ & .329 & .406 & .611 & .6464 & .3536 \\
\hline $\mathrm{X}_{9}$ & .837 & .434 & .144 & .9097 & .0903 \\
\hline $\mathrm{X}_{10}$ & .881 & .382 & .122 & .9370 & .0630 \\
\hline$X_{11}$ & .134 & .184 & .892 & .8475 & .1525 \\
\hline $\mathrm{X}_{12}$ & .416 & .748 & .207 & .7754 & .2246 \\
\hline
\end{tabular}




\section{REFERENCES}

[1] Armstrong A, Francis R, Bourne M, Dussuyer I. Difficulties of Developing and Using Social Indicators to Evaluate Government Programs: Acritical review. Australasia: Wollongong; Paper presented at the 2002 Australasian Evaluation Society International Conference. (Retrieved on October 20, 2009, from www.aes.asn.au.)

[2] Atkinson T, Cantillion B, Marlier E, Nolan B. Social Indicators: The EU and Social Inclusion. New York: Oxford University; 2002.

[3] Biswas B, Caliendo F. A Multivariate Analysis of the Human Development Index. Indian: The Indian Economic Journal (Indian Economic Association). 2003 January-March; 49(4): 96-100P.

[4] Davies A, Quinlivan G. A Panel Data Analysis of the Impact of Trade on Human Development. The Journal of Socio-Economics. 2006 October; 35(5).

[5] Frones I. Theorizing Indicators - on Indicators, Signs and Trends. Social Indicators Research. 2007 August; 83(1):5-23P

[6] Jany-Catrice F, Marlier G. Regional Indicators of Well-Being: The Case of France. Dordrecht: Springer; 2013. Community Quality-of-Life Indicators: Best Cases VI(4): 19-44P.

[7] Khan H, Islam I. Regional Disparities in Indonesia a Social Indicators Approach. Social Indicators Research. 1990 February; 22(1): 69-81P.

[8] Kundu A, Shariff A, Ghosh P K. Indexing Human Development in India: Indicators: Scaling and Composition New Delhi: Narinder Sapra; 2002 April. Programme of Research on Human Development of the National Council of Applied Economic Research (NCAER); United Nations Development Programme (UNDP), Series (83). (Available at: www.ncare.org).

[9] Mc Granahan, Donald V. Analysis of Socio-Economic Development through a System of Indicators. The Annals of the American Academy of Political and Social Science. 1971 Jan; 393: 65-81P.

[10] Measuring Progress Sustainable Development Indicators
2010. National Statistics Compendium Publication.

[11] Department for Environment, Food and Rural Affairs. 2010. (Available at: $w w w . d e f r a . g o v . u k$ ).

[12] Noorbakhsh F. Modified Human Development Index. World Development. 1998 March; 26(.3): 517-528P.

[13] Noorbakhsh F. The Human Development Index: Some Technical Issues and Alternative Indices. Journal of International Development. 1998 August; 10(15): 589-605P.

[14] Organization for Economic Co-operation and Development (OECD). The OECD Social Indicator Development Program: List of Social Concerns Common to Most OECD Countries. Paris: OECD. 1973.

[15] Organization for Economic Co-operation and Development (OECD). Society at a Glance: OECD Social Indicators. Paris. 2001 September. PAC/COM/PUB.

[16] Ray A K. On the measurement of certain aspects of social development. Social Indicators Research. 1989 February; 21(1): 35-92P.

[17] Ray A K. Mean Measurement of Social Development: an International Comparison. Social Indicators Research. 2008 March; 86(1): 1-46P.

[18] Rencher AC. Methods of Multivariate Analysis. New York: John Wiley \& Sons. 2002. Series in Probability and statistics. Second Edit.

[19] Rodrigo G V. The Human Development Index and its Application to States in Mexico. México. 2002. Banco de México: Dirección de Estudios Económicos.

[20] Srimanta M. Regional Analysis of Human Development in Canada. London: University of Western Ontario; Population Studies Center. 1999. Discussion Papers Series; 13(9).

[21] Streeten P. Looking Ahead: areas of future research in human development. Journal of Human Development. 2000 February. 1(1): 25-48P.

[22] United Nations Development Program. Human Development Report 2002. (Available at: http://hdr.undp.org).

[23] Veenhoven R. Social Development and Happiness in Nations. 2012 August. Indices of Social Development, International Institute of Social Studies. 